\title{
ВПЛИВ СОЛЕЙ ВАЖКИХ МЕТАЛІВ І ГЛІФОСАТУ НА ЛІПІДНИЙ ОБМІН
}

Вступ. Свинець, як і всі важкі метали, є протоплазматичною отрутою, що викликає зміни в усіх органах та тканинах. Потрапляючи в організм, він порушує фрерментативні реакції, пригнічує імунобіологічну резистентність організму, синтез білків, ліпідів, вуглеводів та їх метаболізм. Порушення обміну ліпідів та ліпопротеїнів відіграє важливу роль у різних патологічних процесах, сприяє розвитку серцево-судинних захворювань, захворювань печінки, нирок та ін.

Мета дослідження - вивчити комбіновану дію солей важких металів (Плюмбуму і Купруму) та фросфророрганічного пестициду раундапу на показники ліпідного обміну в плазмі крові щурів.

Методи дослідження. Досліди проводили на лабораторних нелінійних білих статевозрілих щурах-самцях, яким внутрішньошлунково протягом 30-ти днів вводили водні розчини Плюмбуму ацетату, Купруму сульфрату і гліфосату (у фрормі гербіциду раундапу). Порушення ліпідного обміну в уражених тварин визначали за зміною у сироватці крові загальних ліпідів, тригліцеридів, загального холестеролу, ліпопротеїнів високої та низької щільності.

Результати й обговорення. Встановлено, що введення щурам водних розчинів Плюмбуму ацетату, Купруму сульфрату і раундапу в комбінації та окремо призвело до зниження в плазмі крові уражених тварин вмісту ліпопротеїнів високої щільності, тригліцеридів, підвищення вмісту загальних ліпідів, загального холестеролу та ліпопротеїнів низької щільності.

Висновок. Введення щурам Плюмбуму ацетату, Купруму сульфрату і раундапу призводить до порушення показників ліпідного обміну в крові тварин.

КЛЮЧОВІ СЛОВА: ліпіди; ліпідний обмін; Плюмбуму ацетат; Купруму сульфат; гліфосат.

ВСТУП. Серед різних хімічних забруднювачів навколишнього середовища особливу небезпеку становлять метали, а саме ті, що мають високу кумулюючу здатність і є стабільними, які широко використовуються в промисловості й у великій кількості містяться в повітрі, ґрунті та воді сучасних міст. Дані токсикометрії дозволили встановити порівняльну токсичність усіх металів періодичної системи Д. І. Менделєєва [1]. Якщо токсичність натрію взяти за одиницю, то токсичність ртуті, міді та свинцю буде майже у 2000 разів вищою. Усі метали за ступенем токсичності можна поділити на три групи: високотоксичні, помірно токсичні й малотоксичні. Найчисленнішою є група помірно токсичних металів, яка характеризується здатністю викликати хронічні отруєння з різноманітними клінічними проявами.

Про отруєння сполуками важких металів відомо 3 давніх часів. Основними шляхами надходження їх в організм є шлунково-кишковий (с) М. М. Корда, Є. Б. Дмухальська, Т. Я. Ярошенко, 2018. тракт та дихальна система, які найбільш вразливі до дії техногенних екотоксикантів. При інтоксикації організму насамперед відбуваються зміни фрункціонування імунної, ендокринної і центральної нервової систем, які супроводжуються порушенням обміну речовин та інших патологічних процесів [2, 3].

Солі металів, потрапляючи в організм, розпадаються на іони, утворюючи важкорозчинні гідроксиди, фросфрати й інші стійкі комплекси, які всмоктуються в шлунково-кишковому тракті та, надходячи у кров'яне русло, швидко переносяться в органи, де здатні накопичуватися. У тканинах вони зазвичай відкладаються у вигляді комплексних сполук з білками, амінокислотами, що впливає на фрункції органів і систем організму $[4,5]$.

Не менш токсичними є фоссфорорганічні сполуки, які широко застосовують у сільському господарстві, промисловості та медицині, серед них - пестициди на основі гліфосату (N-(фоссронометил)-гліцин). Гліфосат малотоксичний для 
ссавців, птахів, риб, однак багаторічне і неконтрольоване використання цього гербіциду для обробки сільськогосподарських культур призвело до забруднення ґрунтів, водойм та потрапляння гліфросату і його метаболітів у продукти харчування. Як і важкі метали, фоосфорорганічні пестициди впливають на метаболізм речовин в організмі людини [6].

Мета дослідження - вивчити комбіновану дію солей важких металів (Плюмбуму і Купруму) та фросоророрганічного пестициду раундапу на показники ліпідного обміну в плазмі крові щурів.

МЕТОДИ ДОСЛІДЖЕННЯ. 3 метою вивчення впливу важких металів у поєднанні з фроссророрганічними пестицидами на ліпідний обмін використовували лабораторних нелінійних білих статевозрілих (середніх масою 170-210 г і віком 5-8 місяців) щурів-самців.

Інтоксикацію в щурів моделювали шляхом щоденного перорального введення впродовж 30-ти діб водних розчинів Плюмбуму ацетату в дозі 11 мг/кг маси тіла (1/20 LD $\left.{ }_{50}\right)$, Купруму сульфрату в дозі 13 мг/кг маси тіла (1/20 LD $\left.{ }_{50}\right)$, гліфосату (у формі гербіциду раундапу) в дозі 250 мг/кг маси тіла (1/20 LD $\left.{ }_{50}\right)$. Токсиканти вводили в комбінації та окремо. Як контроль використовували інтактних тварин, яким вводили питну водопровідну дехлоровану воду.

Усіх піддослідних тварин було поділено на такі групи: 1-ша - інтактні (контрольні); 2-га щури, уражені Плюмбуму ацетатом; 3-тя - тварини, уражені гліфосатом (у срормі раундапу); 4-та - щури, одночасно уражені Плюмбуму ацетатом, Купруму сульфратом і раундапом. На 31-шу добу після останнього введення ксенобіотиків тварин виводили з експерименту за умов тіопентал-натрієвого наркозу (40 мг/кг маси тварини).

Під час виконання досліджень усі тварини перебували у віварії Тернопільського державного медичного університету імені І. Я. Горбачевського на стандартному раціоні відповідно до санітарно-гігієнічних норм. Утримували щурів і проводили всі експерименти на них із дотриманням національних (Закон України № 3447-IV "Про захист тварин від жорстокого поводження", 2006) та міжнародних (Європейська конвенція про захист хребетних тварин, що використовуються для дослідних та інших наукових цілей, Страсбург, 1986) загальних правил і рекомендацій щодо гуманного поводження 3 лабораторними тваринами [7-9].

Порушення ліпідного обміну в плазмі крові щурів оцінювали за зміною вмісту тригліцеридів (ТГ), загальних ліпідів, загального холестеролу (3XC), ліпопротеїнів високої щільності
(ХС-лПВЩ) і ліпопротеїнів низької щільності (ХС-лПНЩ) із застосуванням стандартних біохімічних тест-наборів “Філісіт-Діагностика" (Україна).

Статистичну обробку цисррових даних здійснювали за допомогою програмного забезпечення Excel ("Microsoft", США) і STATISTICA 6.0 ("Statsoft", США) з використанням непараметричних методів оцінки одержаних даних. Для всіх показників розраховували значення середньої арифметичної вибірки (М), її дисперсії і помилки середньої (m). Достовірність різниці значень між незалежними кількісними величинами встановлювали за допомогою критерію Манна - Уїтні. Зміни вважали статистично достовірними при $\mathrm{p}<0,05$ [10].

РЕЗУЛЬТАТИ Й ОБГОВОРЕННЯ. ОТРУєННЯ щурів солями важких металів і раундапом супроводжувалось значними змінами показників ліпідного обміну. Так, вміст ТГ при дії Плюмбуму ацетату зменшився на 11,7 \%, раундапу - на 13,6 \%, а за їх комбінованої дії - на 21,8 \% порівняно з інтактними тваринами. Подібні зміни вмісту ХС-ЛПВЩ ми спостерігали у плазмі крові інтоксикованих щурів. Цей показник був достовірно нижчим за комбінованої дії досліджуваних ксенобіотиків, ніж при введенні кожного з них окремо, і становив 66,7 \% від рівня контролю.

За даними, наведеними в таблиці 1, у плазмі крові щурів, яким одночасно вводили Плюмбуму ацетат, Купруму сульфрат, раундап та окремо Плюмбуму ацетат у субхронічних дозах, концентрація загального холестеролу суттєво зростала (на 43 і 32 \% відповідно) порівняно 3 інтактними тваринами, тоді як при введенні раундапу - лише на 7 \%. Високий рівень ЗХС у плазмі крові $є$ реакцією на дію токсикантів, яка може сприяти розвитку жирової інсрільтрації і порушенню основних функцій печінки.

Аналогічні зміни вмісту ХС-лПНщ, проте менш виражені, ми засріксували при отруєнні тварин солями важких металів і раундапом. Так, у плазмі крові цей показник становив: за дії Плюмбуму ацетату - 116 \%, раундапу - $110 \%$, при поєднаній дії - 136 \% від рівня інтактних тварин. Результати, наведені в таблиці 1, підтверджують, що за комбінованої дії концентрація ХС-лПНЩ зростала щодо як інтактних тварин, так і щурів, яким окремо вводили раундап та солі важких металів.

При дослідженні ліпідного обміну важливим діагностичним показником $€$ розрахунок співвідношення вмісту ліпідів та вмісту ліпопротеїнів різної щільності. Тому для більш повної оцінки впливу ксенобіотиків на ліпідний обмін ми розрахували співвідношення: ТГ/ХС-ЛПВЩ, ТГ/ЗХС, ХC-лПВщ/XC-лПНщ, ЗХC/XC-лПВщ та коефі- 
Таблиця 1 - Вміст показників ліпідного обміну в плазмі крові щурів, уражених Плюмбуму ацетатом,

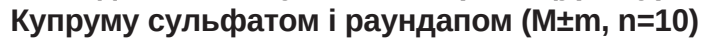

\begin{tabular}{|c|c|c|c|}
\hline \multicolumn{4}{|c|}{ Група тварин } \\
\hline \multirow{2}{*}{ інтактні } & \multicolumn{3}{|c|}{ уражені } \\
\hline & $\left(\mathrm{CH}_{3} \mathrm{COO}\right)_{2} \mathrm{~Pb}$ & гліфросат & комбінована дія \\
\hline \multicolumn{4}{|c|}{ Тригліцериди, ммоль/л } \\
\hline $2,06 \pm 0,03$ & $\begin{array}{c}1,82 \pm 0,14 \\
p_{1}<0,001\end{array}$ & $\begin{array}{c}1,78 \pm 0,11 \\
p_{1}<0,001\end{array}$ & $\begin{array}{c}1,61 \pm 0,09 \\
p_{1}<0,001\end{array}$ \\
\hline \multicolumn{4}{|c|}{ Загальний холестерол, ммоль/л } \\
\hline $2,18 \pm 0,09$ & $\begin{array}{c}2,87 \pm 0,09 \\
p_{1}<0,01\end{array}$ & $\begin{array}{c}2,34 \pm 0,28 \\
p_{1}<0,01\end{array}$ & $\begin{array}{l}3,12 \pm 0,21 \\
p_{1}<0,001\end{array}$ \\
\hline \multicolumn{4}{|c|}{ ХС-ЛПВЩ, ммоль/л } \\
\hline $1,38 \pm 0,02$ & $\begin{array}{c}1,19 \pm 0,06 \\
p_{1}<0,01\end{array}$ & $\begin{array}{c}1,24 \pm 0,05 \\
p_{1}<0,001\end{array}$ & $\begin{array}{c}0,92 \pm 0,07 \\
p_{1}<0,01\end{array}$ \\
\hline \multicolumn{4}{|c|}{ ХС-ЛПНЩ, ммоль/л } \\
\hline $1,85 \pm 0,07$ & $\begin{array}{c}2,14 \pm 0,02 \\
p_{1}<0,001\end{array}$ & $\begin{array}{c}2,04 \pm 0,22 \\
p_{1}<0,001\end{array}$ & $\begin{array}{c}2,52 \pm 0,13 \\
p_{1}<0,001\end{array}$ \\
\hline
\end{tabular}

цієнт атерогенності ((ЗХС-ХС-лПВЩ)/ХС-лПВЩ), зміни яких свідчать про ризик розвитку атеросклерозу.

За комбінованої дії ксенобіотиків співвідношення ТГ/ЗХС знизилося на $45 \%$, ХС-лПВщ/ ХC-лПнЩ - на 51 \%, а співвідношення ТГ/ ХС-лПВЩ і 3ХC/XС-ЛПВЩ зросли в 1,2 та 2,2 раза відповідно від рівня контролю (табл. 2).

За даними, наведеними в таблиці 2, коефіцієнт атерогенності, який відображає співвідно- шення атерогенних і неатерогенних ліпопротеїнів, зростав у тварин всіх уражених груп. При введенні щурам раундапу він становив $153 \%$, Плюмбуму ацетату - 243 \%, за комбінованої дії - 412 \% від рівня інтактних тварин.

Аналізуючи отримані результати, можна вважати, що при тривалій інтоксикації важкими металами і гербіцидом раундапом порушуються вміст і співвідношення всіх класів ліпідів.

Таблиця 2 - Динаміка змін співвідношень показників ліпідного обміну та коесріцієнт атерогенності в плазмі крові щурів, уражених Плюмбуму ацетатом, Купруму сульсратом і раундапом (M $\pm m, n=10)$

\begin{tabular}{|c|c|c|c|}
\hline \multicolumn{4}{|c|}{ Група тварин } \\
\hline \multirow{2}{*}{ інтактні } & \multicolumn{3}{|c|}{ уражені } \\
\hline & $\left(\mathrm{CH}_{3} \mathrm{COO}\right)_{2} \mathrm{~Pb}$ & гліфосат & комбінована дія \\
\hline \multicolumn{4}{|c|}{$\mathrm{T} Г / 3 \mathrm{XC}$} \\
\hline $0,94 \pm 0,07$ & $\begin{array}{c}0,63 \pm 0,14 \\
p_{1}<0,001\end{array}$ & $\begin{array}{c}0,76 \pm 0,09 \\
p_{1}<0,001\end{array}$ & $\begin{array}{c}0,52 \pm 0,10 \\
p_{1}<0,001\end{array}$ \\
\hline \multicolumn{4}{|c|}{ ТГ/ХС-ЛПВЩ } \\
\hline $1,49 \pm 010$ & $\begin{array}{c}1,53 \pm 0,09 \\
p_{1}<0,001\end{array}$ & $\begin{array}{l}1,44 \pm 0,11 \\
p_{1}<0,001\end{array}$ & $\begin{array}{c}1,75 \pm 0,09 \\
p_{1}<0,001\end{array}$ \\
\hline \multicolumn{4}{|c|}{ 3ХС/ХС-ЛПВЩ } \\
\hline $1,56 \pm 0,13$ & $\begin{array}{c}2,41 \pm 0,14 \\
p_{1}<0,001\end{array}$ & $\begin{array}{l}1,89 \pm 0,11 \\
p_{1}<0,001\end{array}$ & $\begin{array}{c}3,39 \pm 0,12 \\
p_{1}<0,001\end{array}$ \\
\hline \multicolumn{4}{|c|}{ ХС-лПВЩ/ХС-лПНЩ } \\
\hline $0,75 \pm 0,07$ & $\begin{array}{l}0,56 \pm 0,04 \\
p_{1}<0,001\end{array}$ & $\begin{array}{l}0,61 \pm 0,11 \\
p_{1}<0,001\end{array}$ & $\begin{array}{c}0,37 \pm 0,10 \\
p_{1}<0,001\end{array}$ \\
\hline \multicolumn{4}{|c|}{ Коефріцієнт атерогенності } \\
\hline $0,58 \pm 0,07$ & $\begin{array}{l}1,41 \pm 0,04 \\
p_{1}<0,005\end{array}$ & $\begin{array}{c}0,89 \pm 0,11 \\
p_{1}<0,01\end{array}$ & $\begin{array}{c}2,39 \pm 0,10 \\
p_{1}<0,001\end{array}$ \\
\hline
\end{tabular}

ВИСНОВКИ. 1. Ураження щурів Плюмбуму ацетатом, Купруму сульсратом і раундапом окремо та в комбінації супроводжується зниженням у крові тварин вмісту ліпопротеїнів високої щільності, тригліцеридів, підвищенням вмісту загальних ліпідів, загального холестеролу та ліпопротеїнів низької щільності.

2. Інтоксикація щурів важкими металами i раундапом призводить до порушення співвідно- шення між ліпідами у тварин усіх досліджуваних груп.

3. Коефіцієнт атерогенності зростає в плазмі крові уражених ксенобіотиками щурів порівняно з інтактними тваринами.

Перспективи подальших досліджень. Плануємо визначити вплив пептидів на ліпідний обмін у щурів за комплексної дії Купруму сульфрату, Плюмбуму ацетату та раундапу. 


\section{СПИСОК ЛІТЕРАТУРИ}

1. Цыганков В. Г. Изменение синтеза РНК под влиянием ионов свинца в иммунокомпетентных клетках / В. Г. Цыганков, Т.В.Латушко, Е.В.Барковский // Здоровье и окружающая среда : сб. науч. тр. - Мн., 2001. - С. 393-397.

2. Барковский Е. В. Молекулярные основы цитотоксичности свинца : монография / Е. В. Барковский, Т. В. Латушко ; под общ. ред. Е. В. Барковского. - Мн. : БГМУ, 2006. - 99 с.

3. Трахтенберг И. М. Книга о ядах и отравлениях // И. М. Трахтенберг. - К. : Наукова думка, 2000. - 366 с.

4. Колесников В. А. Воздействие тяжелых металлов на биохимические реакции / В. А. Колесников // Вестн. Краснояр. гос. аграр. ун-та, 2009. - С. 106-109.

5. Гнатейко О. 3. Екогенетичні аспекти патології людини, спричиненої впливом шкідливих фракторів зовнішнього середовища / О. З. Гнатейко, Н. С. Лук'яненко // Здоровье ребенка. -2007. - № 6 (9). - С. 82-87.
6. Safety of Genetically Engineered Foods: Approaches to Assessing Unintended Health Effects. Institute of Medicine and National Research Council of the National Academies 2004, p. 256 (https://www.nap.edu/catalog/10977/safety-of-genetically-engineered-foodsapproaches-to-assessing-unintended-health).

7. Про захист тварин від жорстокого поводження : Закон України від 21.02.2006 р. № 3447-IV.

8. Науково-практичні рекомендації з утримання лабораторних тварин та роботи з ними / Ю. М. Кожем'якін, О. С. Хромова, М. А. Філоненко, Г. А. Сайфетдінова. - К. : Авіцена, 2002. - 156 с.

9. European convention for the protection of vertebrate animals used for experimental and other scientific purposes. - Council of Europe. Strasbourg, 1986. No. 123. -52 p.

10. Bernard Rosner. Fundamentals of Biostatistics. Boston, USA. - 2010. - 859 p.

\section{REFERENCES}

1. Tsygankov, V.G., Latushko, T.V., \& Barkovskiy E.V. (2001). Izmenenie sinteza RNK pod vliyaniem ionov svintsa $v$ immunokompetentnykh kletkah [The influence of lead ions on the change of synthesis RNA in immunocompetent cells]. Zdorovye i okruzh. sreda: sb. nauch. tr. - Health and Environment: a collection of Scien. works, Minsk [in Russian].

2. Barkovskiy, E.V., \& Latushko, T.V. (2006). Molekulyarnye osnovy tsitotoksichnosti svintsa: monografiya [Molecular bases of lead cytotoxicity: monograph]. Barkovskiy, E.V. (Ed.). Minsk: BSMU [in Russian].

3. Trakhtenberg, I.M. (2000). Kniga o yadakh i otravleniyakh [The book on poisons and poisoning]. Kyiv: Naukova dumka [in Russian].

4. Kolesnikov, V.A. (2009). Vozdeystvye tyazhelykh metallov na biokhimicheskiye reaktsyy [Influence of heavy metals on biochemical reactions] Vestnik Krasnoyarskogo gosudarstvennogo agrarnogo universiteta - Bulletin of the Krasnoyarsk State Agrarian University, 106-109 [in Russian].

5. Hnateiko, O.Z., \& Lukianenko, N.S. (2007). Ekohenetychni aspekty patolohii liudyny, sprychynenoi vplyvom shkidlivykh faktoriv zovnishnoho seredovyshcha
[Ecogenetic aspects of human pathology, caused by harmful factors of the environment]. Zdorovye rebenka Child Health, 6 (9), 82-87 [in Ukrainian].

6. Safety of Genetically Engineered Foods: Approaches to Assessing Unintended Health Effects. Institute of Medicine and National Research Council of the National Academies 2004, p. 256 (https://www.nap.edu/catalog/10977/safety-of-genetically-engineered-foodsapproaches-to-assessing-unintended-health).

7. Zakon Ukrainy "Pro zakhyst tvaryn vid zhorstokoho povodzhennia" vid 21.02.2006 r., No 3447 [The Law of Ukraine "On the Protection of animals from ill-treatment" of 02.21. 006, No. 3447] [in Ukrainian].

8. Kozhemiakin, Yu.M., Khromova, O.S., Filonenko, M.A., \& Saifetdinova, H.A. (2002). Naukovo-praktychni rekomendatsii zutrymannia laboratornykh tvaryn ta robota z nymy [Scientific and practical recommendations for the maintenance of laboratory animals and work with them]. Kyiv: Avitsena [in Ukrainian]

9. (1986). European convention for the protection of vertebrate animals used for experimental and other scientific purposes. Council of Europe. Strasbourg.

10. Bernard Rosner (2010). Fundamentals of Biostatistics. Boston, USA. 


\section{ВЛИЯНИЕ СОЛЕЙ ТЯЖЕЛЫХ МЕТАЛЛОВ И ГЛИФОСАТА НА ЛИПИДНЫЙ ОБМЕН}

\section{Резюме}

Вступление. Свинец, как и все тяжелые металлы, является протоплазматическим ядом, который вызывает изменения во всех органах и тканях. Попадая в организм, он нарушает фрерментативные реакции, подавляет иммунобиологическую резистентность организма, синтез белков, липидов, углеводов и их метаболизм. Нарушение обмена липидов и липопротеинов играет важную роль в различных патологических процессах, способствует развитию сердечно-сосудистых заболеваний, заболеваний печени, почек и др.

Цель исследования - изучить комбинированное действие солей тяжелых металлов (свинца и меди) и фросфророрганического пестицида раундапа на показатели липидного обмена в плазме крови крыс.

Методы исследования. Опыты проводили на лабораторных нелинейных белых половозрелых крысах-самцах, которым внутрижелудочно в течение 30-ти дней вводили водные растворы ацетата свинца, сульфрата меди и глифросата (в фрорме гербицида раундапа). Нарушение липидного обмена в пораженных животных определяли по изменению в сыворотке крови общих липидов, триглицеридов, общего холестерола, липопротеинов высокой и низкой плотности.

Результаты и обсуждение. Установлено, что введение крысам водных растворов ацетата свинца, сульфрата меди и раундапа в комбинации и отдельно привело к снижению в плазме крови пораженных животных содержания липопротеинов высокой плотности, триглицеридов и повышению содержания общих липидов, общего холестерола и липопротеинов низкой плотности.

Вывод. Введение крысам ацетата свинца, сульфрата меди и раундапа приводит к нарушению показателей липидного обмена в крови животных.

КЛЮЧЕВЫЕ СЛОВА: липиды; липидный обмен; ацетат свинца; сульфат меди; глифосат.

M. M. Korda, Ye. B. Dumukhalska, T. Ya. Yaroshenko I. HORBACHEVSKY TERNOPIL STATE MEDICAL UNIVERSITY

\section{THE EFFECT OF HEAVY METALS SALTS AND GLYPHOSATE ON THE LIPID METABOLISM}

\section{Summary}

Introduction. Lead is a protoplasmic poison harmful to varieties of organs and tissues as all heavy metals. Get into the body it violates enzymatic reactions, depresses the immunobiological resistance of the organism, syntheses of proteins, lipids, carbohydrates, and their metabolism. Lipid and lipoprotein abnormalities play a key role in the most pathogenesis process: progression of cardiovascular diseases, liver diseases, kidney diseases and other.

The aim of the study - to research the effect of the combined action of heavy metals salts (lead and copper) and organophosphorus roundup pesticide on indices of lipid metabolism in blood plasma of rats.

Research Methods. Experiments were performed on mature lab nonlinear white male rats with body weight of 150-200 g, which were injected intragastrically for 30 days with the lead acetate, the copper sulfate, the glyphosate (in herbicide Roundup). The disorders of lipid metabolism indices were detected by the changes in blood serum the following were estimated: total lipid, triglycerides, total cholesterol, high-density and low density lipoproteins.

Results and Discussion. It was established that when administered to rats of aqueous solutions, lead acetate, copper sulfate and roundup in combination and separately led to a decrease in blood plasma of affected animals with high density lipoproteins, triglycerides, increased total lipids, total cholesterol and low density lipoprotein.

Conclusion. Introduction to rats lead acetate, copper sulfate and roundup resulted in a violation of lipid metabolism in animal blood.

KEY WORDS: lipids; lipid metabolism; lead acetate; copper sulfate; glyphosate.

Отримано 25.10.18

Адреса для листування: Є. Б. Дмухальська, Тернопільський державний медичний університет імені І. Я. Горбачевського, майдан Волі, 1, Тернопіль, 46001, Україна, e-mail: dmukhalska@tdmu.edu.ua. 